The Evolution of Equity Crowdfunding: Insights from Co-investments of Angels and the Crowd

\author{
Wanxin Wang ${ }^{\mathrm{a}^{*}}$, Ammara Mahmood $^{\mathrm{b}}$, Catarina Sismeiro ${ }^{\mathrm{c}}$, Nir Vulkan $^{\mathrm{d}}$ \\ ${ }^{\text {a }}$ PhD Candidate, Imperial College Business School, Imperial College London, SW7 2AZ, \\ London, UK.wanxin.wang13@imperial.ac.uk \\ ${ }^{\mathrm{b}}$ Assistant Professor in Marketing, Lazaridis School of Business \& Economics, Wilfrid \\ Laurier University, ON N2L 3C5, Waterloo, Canada. ammahmood@wlu.ca \\ $\subseteq$ Associate Professor in Marketing, Imperial College Business School, Imperial College \\ London, SW7 2AZ, London, UK.c.sismeiro@imperial.ac.uk \\ d-Associate Professor of Business Economics, Saïd Business School, University of Oxford, \\ OX1 1HP, Oxford, UK. Nir.Vulkan@sbs.ox.ac.uk
}

*Corresponding author. wanxin.wang13@imperial.ac.uk 


\title{
The Evolution of Equity Crowdfunding: Insights from Co-investments of Angels and the Crowd
}

\begin{abstract}
Equity crowdfunding platforms are at the center of the digital transformation of early-stage venture funding. These digital platforms were originally heralded as a democratizing force in early stage finance, due to their role in facilitating the exchange between entrepreneurs and a multitude of non-professional small investors ("the crowd"). Equity crowdfunding platforms have experienced considerable growth and now attract professional investors including business angels. The presence of angels alongside the crowd on equity crowdfunding platforms has raised questions whether these digital platforms can continue to play their role in democratizing access to capital. Using data from a leading equity crowdfunding platform, we examine the interplay between the investment decisions of angels and the crowd. We find evidence of information flows in crowdfunding platforms between angels, and from angels to the crowd. We find angels play an important role in funding of large ventures, whereas the crowd not only fill the funding gaps for such large ventures but also play a pivotal role in the funding of small ones. The complementarity between angels and crowd investors seems to increase the overall efficiency in an otherwise highly asymmetric and uncertain market, confirming that digitization can indeed bring important benefits to venture investment.
\end{abstract}

Keywords: Equity crowdfunding; Angel investment; Signaling

JEL codes: G23, G21, L26, G11, G40

\section{Highlights:}

Equity crowdfunding platforms attract angels and larger ventures

Angels take the lead in large ventures and crowd investors fill funding gaps

High-contribution pledges by angels' act as signals of venture quality

Signal effectiveness depends on venture type and social proximity between sender and recipient 


\section{Introduction}

Raising finance is one of the most challenging aspects of entrepreneurship (Lee et al., 2015). Direct investments into start-up businesses, the majority of which are likely to fail, are highrisk and start-up entrepreneurs often have limited access to traditional sources of financing. The financial crash of 2008 created additional barriers to early stage funding, which in turn gave impetus to regulators in the United Kingdom (UK) to facilitate access to capital for early-stage ventures (Mollick and Robb, 2016). Regulators actively supported fintech start-ups with the goal to reduce the dominance of institutional investors (Hernando, 2016).

As a result, the Financial Conduct Authority (FCA) has adopted a light touch approach towards Equity Crowdfunding (ECF) regulations in the UK (Vulkan et al., 2016). In addition, to encourage the public to invest in start-ups, the UK government offered generous tax incentives through the Seed Enterprise Investment Scheme (SEIS) and the Enterprise Investment Scheme (EIS). With these incentives in place and their simple-to-use digital interface enabling easy-to-access venture information, ECF platforms quickly gained popularity among the public. These digital platforms, which differ significantly from traditional sources of financing, have increased optimism regarding the future of start-up finance, with ECF raising 1,130 million USD in funding in the UK alone (Statista, 2018), and is now the second largest investment category in the UK (by number of companies funded) after venture capitalists (Beauhurst, 2017).

ECF platforms not only attract non-professional small investors ("the crowd"), but also attract angel investors and venture capitalists (VC) interested in diversification or convenience. As such ECF platforms provide a wide range of potentially high-return early-stage ventures with the opportunity to spread risk across multiple ventures and limited administrative burden for investors seeking passive investments (AIG, 2016; Landström and Mason, 2016).

Beyond the convenience, digital ECF platforms also provide entrepreneurs the ability to use media such as video and images to provide campaign information and to post real-time 
updates to signal venture quality. However, information asymmetry still presents a challenge on crowdfunding platforms (Ahlers et al., 2015) and finding the right balance between facilitating fundraising for new ventures and protecting non-professional investors from illadvised decisions and even financial ruin is non-trivial.

In this respect, some argue that professional and angel investors can play an important signaling role on these platforms (Agrawal et al., 2016), making the increasing presence of angels and VCs on ECF platforms a positive development (BBB \& UKBAA, 2017; Mason and Botelho, 2014). Leading ECF platforms such as Crowdcube and CircleUp actively encourage co-investment between the crowd and large investors (TechCrunch, 2016). On the other hand, some commentators argue that large investors will eventually dominate these platforms and weaken the democratizing purpose of these new financing channels (Zhang et al., 2015). However, the impact of large investors such as angels on ECF is yet unclear and, to the best of our knowledge, prior research has not studied how angels and crowd investors interact on digital crowdfunding platforms.

The evolution of ECF platforms can have long-lasting repercussions for the funding of early-stage ventures in terms of the types of ventures being funded, the way in which entrepreneurs pitch campaigns, and the nature of innovation (Zhang et al., 2015). It is therefore imperative to determine how angels and crowd investors interact on these digital platforms. Are angels "crowding out" crowd investors, or can angels help reduce information asymmetries by providing valuable and informative signals to the crowd? If angels dominate the platforms, the digitization would only benefit large investors and perpetuate funding imbalances associated with conventional funding.

We seek to address these questions by analyzing one of UK's leading ECF platforms from July 2012 until August 2017. Over this period, we observe an increasing trend in terms of both volume and fundraising success of large ventures with a funding goal higher than $£ 100,000$ on the platform (ventures raising funding are called "campaigns" and we use these terms 
interchangeably). We also notice an increase in the volume and value of investments by large investors who correspond to the top $1 \%$ in terms of total amount invested and are behaviorally similar to business angels. Despite the growth in the number of large ventures and angel investors, we observe that crowd investors not only complement angels in large campaigns but also play a significant role in funding small campaigns that might not generate sufficient interest from angels. Hence, the fear that ECF platforms will evolve into digital marketplaces dominated by entrepreneurs with large funding needs and large investors such as angels who can fund these needs, seems unfounded. ECF platforms seem to have retained their democratic structure and the fast-paced flows of information between diverse investors on these dynamic digital platforms have facilitated the access to capital for both small and large ventures, previously unserved by traditional offline sources of finance.

To study the co-investment behavior of angels and crowd investors, we employ the theoretical lens of signaling theory (Connelly et al., 2011 for a review). We propose and demonstrate that high-contribution pledges (i.e., pledges contributing a high percentage to a campaign's funding goal) serve as an effective investor-generated signal of venture quality because they are costly and difficult to imitate. In addition, we propose and show that angel investments are more informative compared to crowd investments. We further show that perceived similarity between signal recipient and sender enhances information flow resulting in angels (compared to crowd investors) reacting more positively to high-contribution pledges from other angels. However, the size of the venture moderates this effect, suggesting that the effectiveness of angel-generated signals depends on the funding context.

Our results show that ECF investors rely on high-contribution pledges in general and on angel pledges in particular to inform their funding decisions. In light of the signaling role played by angel pledges, regulators ought to focus on further incentivizing and facilitating information flow that reduces market frictions while protecting crowd investors from being misled (FCA, 2018). Considering the impersonal nature of digital crowdfunding, information asymmetry and 
the risks for inexperienced investors, there is a need to enhance standardized regulations on investor information disclosure, platform due-diligence, and explicit investor categorization. Such regulatory measures would increase transparency and facilitate information flow, further enhancing the benefits and efficiency gains from the digitization of early stage finance.

\section{Literature Review and Hypotheses}

\subsection{Angel investors in ECF}

Angels are generally defined as "high net worth individuals who invest their own money, either alone or with others, directly in unquoted businesses in which there is no family connection" (Mason et al., 2016, p.322). Angels are a diverse group (Drover et al., 2017; Wright et al., 2015) that varies on demographical and behavioral dimensions (Sørheim and Botelho, 2016). While most angels make individual investment decisions other angels invest via "angel networks" comparable to investor-led ECF platforms (e.g., Angel's Den, Syndicate Room) where investors pledge by following a lead investor (Agrawal et al., 2016). Other investors invest via informal offline investment networks and recently via online company-led ECF platforms like the one we study.

Angels usually concentrate their investments in specific markets or sectors to leverage their experience and expertise (Maula et al., 2005; Wright and Westhead, 1998). However, there is also evidence that angels diversify their investments with some angels holding a portfolio of more than 20 different ventures at a time (BBB and UKBAA, 2017). In addition, whereas angels have traditionally maintained personal contact with entrepreneurs (Mason and Botelho, 2014; Sørheim and Botelho, 2016), some angels are more hands-off with limited interest in managerial support (e.g., Erikson et al., 2003; Sørheim and Landström, 2001). Further, microlending and crowdfunding platforms have gained popularity among younger and less experienced angels seeking convenience (Wright et al., 2015) and even hands-on angels who are willing to hold passive investments (Landström and Mason, 2016). Hence, ECF platforms are likely most attractive to angels seeking diverse ventures and convenience. These investors 
can in turn influence the investment dynamics on these digital platforms by providing signals to other investors.

\subsection{Investor generated signals in ECF}

ECF is characterized by high uncertainty due to the information asymmetry between entrepreneurs and investors, the short fundraising time frames (30 to 60 days), the early stage of ventures, and limited offline contact with entrepreneurs. In this context, signals of venture quality (i.e., informative cues of the venture's ability to earn a positive cash flow) as proposed by signaling theory gain importance (Vismara, 2016a).

Previous research has identified several campaign-level attributes such as share of equity offered, and entrepreneurs' social, human, and intellectual capital as effective signals (Ahlers et al., 2015; Vismara, 2016a). Similarly, communication with investors (Block et. al., 2018), narrative style (Parhankangas and Renko, 2017) and visual cues (Mahmood et al., 2018) are used by entrepreneurs as signals of venture quality. In addition, signals from sources other than entrepreneurs can disambiguate the effect of several entrepreneur-generated signals (Plummer et al., 2016). For instance, third-party signals such as endorsements from angels and VCs and the investment decisions by other investors have been found to influence start-up success (Kuppuswamy and Bayus, 2017).

According to signaling theory, an effective signal is costly, difficult to replicate, and contains private information (Spence, 1973). A high-contribution pledge in a specific venture can convey the investor's confidence in the venture and, if costly to replicate, can serve as an effective signal of venture quality to other investors. ECF platforms often list previous pledges for a specific venture in descending order by value, these digital platforms thus facilitate interinvestor signaling by giving more visibility to large pledges. Not surprisingly, recent crowdfunding studies find that large investments in a venture influence subsequent investors (Burtch et al., 2013). Consequently, large investments from early funders result in a higher 
likelihood of campaign success (Burtch et al., 2013; Vismara, 2016b). Therefore, we hypothesize:

H1: High-contribution pledges in a campaign positively influence the subsequent amount pledged by investors in the same campaign.

\subsection{Identity of signal sender}

Bernstein et al. (2016) note that investors may focus more on the identity of previous investors to assess venture quality in markets with information asymmetry. Hence, we propose that the identity of the investor generating the high-contribution pledge is likely to influence how investors interpret investment signals.

Previous literature on signaling and information exchange stresses the differing credibility and trustworthiness of signals depending on their source (e.g., Gomulya and Mishina, 2017; Kang and Herr, 2006). For instance, observable endorsements from experts have been found to be effective signals of venture quality (Courtney et al., 2017; Kim and Viswanathan, 2018). Similarly, investors' pledges can be seen as endorsements as they reflect the investors' commitment towards the venture. Given the large distinction in wealth, expertise, and experience between angels and crowd investors (Hornuf and Schwienbacher, 2016), investments from angels will be deemed more informative and will thus be more influential in generating subsequent pledges for a venture. Further, angel investments are associated with higher survival and growth rate of ventures (Kerr et al., 2011) and help attract VCs and other institutional investors (Wallmeroth et al., 2018). We therefore hypothesize:

H2: High-contribution pledges made by angels in a campaign have a greater influence on subsequent amount pledged by investors in the same campaign, compared to high contribution pledges made by crowd investors.

\subsection{Identity of signal recipient}

Beyond the importance of the signal source, signal decoding, may also play an important role. However, decoding signals is susceptible to the characteristics of the recipient (Connelly et al., 2011). Information exchange theories suggest that individuals perceive information delivered 
by those similar to themselves as more useful (Brack and Benkenstein, 2012). Social proximity, or perceived similarity between individuals, that is "the degree to which people who interact are similar in beliefs, education, social status" (Rogers and Bhowmik, 1970, p.525) could explain these effects (Cowgill et al., 2009). Prior research shows that crowdfunders from similar social categories are more likely to build connections (Greenberg and Mollick, 2017). Therefore, due to perceived similarity, a high-contribution pledge from an angel is likely to have a greater impact on other angels. Therefore, we hypothesize:

H3: High-contribution pledges by angels in a campaign will have a greater positive effect on the subsequent amount pledged by other angel investors in the same campaign, compared to high-contribution pledges by crowd investors.

\subsection{Signal context}

Signaling theory identifies costliness and ease of replication as key criteria for signal effectiveness (Spence, 1973). High-contribution pledges in campaigns with a large funding goal (large campaigns) are significantly larger in monetary value than those in campaigns with a small funding goal (small campaigns). They are consequently more difficult to imitate and have higher opportunity costs (Connelly et al., 2011). Moreover, large campaigns are subject to higher materialization risk, as they are less likely to meet the funding goal compared to small campaigns (Belleflamme et al., 2013; Mollick, 2014). Because investment riskiness positively moderates people's willingness to refer to opinions of others with similar sentiments (Gu et al., 2014), we expect the positive impact of high-contribution pledges made by angel investors to be higher in large campaigns than in small campaigns. Our final hypotheses are:

H4a: Compared to small campaigns, high-contribution pledges by angels in large campaigns have a greater positive effect on subsequent amount pledged by other angel investors in those same campaigns.

H4b: Compared to small campaigns, high-contribution pledges by angels in large campaigns have a greater positive effect on subsequent amount pledged by crowd investors in those same campaigns.

\section{Data}


We study investor behavior using investment data for 50,999 unique investors and 1,151 unique campaigns from July 2012 to August 2017 on one of UK's leading ECF platforms. ${ }^{1}$ The platform we study acts as the nominee of the participating investors, facilitating future funding rounds and preventing share dilution. It is also similar to other major ECF platforms (e.g., Crowdcube) in terms of size, type, number of deals completed on the platform, and fee structure. It has successfully attracted ventures across 13 sectors, with the most popular being financial services, food \& drink, digital media, entertainment, and technology.

The platform attracts a large number of diverse investors, ranging from non-professional small investors (typically denominated "the crowd") to sophisticated and high-net-worth individuals. Because investors use multiple platforms, the leading ECF platforms tend to have a similar profile of users. ${ }^{2}$ After the public launch of a campaign on the platform, entrepreneurs have 60 days to raise (at least) 100\% of the funding goal. If a campaign does not reach its goal it is deemed unsuccessful and the venture will not be funded (pledges are returned to investors). Campaigns can reach more than $100 \%$ of the funding goal (overfunding is allowed) and prior to the public launch, entrepreneurs can use the platform to raise funds privately (i.e., private launch).

\subsection{Campaign size}

There is considerable variation in the size (funding goal) of the 1,151 campaigns: the average funding goal is $£ 197,821$ with a standard deviation of $£ 317,633$. We conduct a median split of campaigns with respect to their size and classify campaigns with a funding goal higher than $£ 100,000$ as large campaigns, and all others as small campaigns. Table 1 summarizes campaign-level attributes by campaign size.

\subsection{Investor categorization}

We also observe heterogeneity among investors in terms of portfolio size (from 1 to 696

\footnotetext{
${ }^{1}$ A Non-Disclosure Agreement prevents us from disclosing the identity of the platform.

${ }^{2}$ The CEO of the platform notes: "... platforms (at least the major ones) certainly compete with each other for deals; we also compete for investors, although many investors use multiple platforms."
} 
campaigns per investor) and total investment on the platform (from as low as $£ 10$ to $£ 14.4$ million). More importantly, the CEO of the platform confirmed the presence of angels alongside crowd investors. Although we cannot confirm the identity of each angel on the platform, we posit that as long as the behavior of these investors is similar to the behavior reported in previous angel investor studies, it is likely that they will be perceived as business angels by other investors (Lee and Thorson, 2008). Hence, we classify the top $1 \%$ of investors in terms of total amount pledged as angel investors $(N=510)$, and the remaining as crowd investors $(N=50,489)$.

Our analysis reveals that the minimum total amount a single angel investor invested during the period of our study is $£ 66,000$ (although the amount per pledge could be substantially lower). In addition, the behavior of these investors appears similar to that of UK business angels outlined in recent surveys (BBB and UKBAA, 2017). Table 2a presents a comparison of several key metrics including the median investment value per investor, investors' location, the percentage invested in specific sectors, and the size of the investors' portfolios. As we can see from the table, the angel investors we identified are very similar to those in previous studies.

We also randomly selected a sample of 153 investors we classified as angels (i.e., top 1\% of investors) and reviewed in detail their LinkedIn and Crunchbase profiles. By combining the information from the two sources, we find that at least $135(88 \%)$ of investors we classified as angels also qualified as angels based on the criteria that previous research typically uses to profile angels (e.g., UKBAA, 2018). ${ }^{3}$ Some of the investors could not be uniquely identified, either because there were multiple investors with the same name or because some investors had limited profile information. However, being able to link $88 \%$ of our sample to open public profiles of angel investors provides reasonable assurance that our classification is robust.

Because we identify angel investors based on their total amount pledged, our approach could account for angels who make few but very large pledges, and angels who make a larger

\footnotetext{
${ }^{3}$ We checked whether an investor met at least one of the following criteria to be classified as angel: (1) having successfully founded start-ups, (2) having taken any chief executive level roles in companies that they do not own, (3) claiming oneself as a professional/angel investor, and (4) being a fund, a syndicate, or an investment organization.
} 
number of smaller pledges. In line with existing research on angel behavior (Landström and Mason, 2016; Sørheim and Botelho, 2016; Wallmeroth et al., 2018), we observe significant heterogeneity among the identified angels. About $3 \%$ of angels invested more than one million GBP in a single pledge, whereas $28 \%$ made single pledges below $£ 100$ (these accounted for a very small percentage of their entire investments). In addition, although $61 \%$ of identified angels made fewer than five pledges during the entire period, $5 \%$ of angels made more than 90 .

We also observe differences in the timing of investment among angels, with some angels investing only during the private launch and others only during the public launch. According to the platform CEO, entrepreneurs often "soft circle part of their round through offline angels" before the public launch. Angels who invest during the private period through offline contacts are likely to treat ECF as an asset class similar to traditional offline investments, maintaining direct relationship with entrepreneurs and being hands-on. However, investors who invest during the public launch period may consider ECF to be a different asset class, favoring the convenience and hands-off nature of ECF.

In our dataset, we identified those angels who only made pledges during the private launch period (82 angels satisfy this condition) and those who only made investments during the public launch period (168 angels). Angels who only invest during the private launch period likely reveal a preference for an offline connection with entrepreneurs. However, in terms of investment behavior we found no significant difference in the average amount pledged $(£ 117,370$ vs. $£ 146,937, p$-value $=0.25)$, the number of campaigns invested in, preference for small versus large campaigns, and total amount invested (see, Table 2b). Hence, although angels may differ in their preference for involvement in ventures (Sørheim and Botelho, 2016) the investment behavior on the ECF platform is still similar. In contrast, we observe significant differences between investment behavior of angels and that of crowd investors (see, Table 3). For instance, in large campaigns angels make approximately six times the number of pledges of crowd investors, and pledge around 121 times the amount of crowd investors. These results 
provide further assurance that our strategy for angel identification is robust, identifies handson and hands-off angels, and distinguishes angel investors from non-professional small investors.

\subsection{Evolution of the platform}

Since its inception, the platform has registered an increase in both the value and number of pledges. Figures 1 and 2 present monthly total amount pledged and monthly number of pledges between July 2012 and August 2017. Splitting the data by campaign size (Figures 3 and 4), we note a strong increase in the number and success rate of large campaigns over time. We also observe growth in the number of angels joining the platform and the value of angel pledges, with the number and amount pledged by crowd investors remaining stable (Figures 5 and 6 ).

The simultaneous growth in large investors and large campaigns on the platform could support the arguments of those who claim the participation of angels and large investors on ECF platforms poses a risk to the democratizing role of the digitization in early stage finance. However, the increasing presence of angels is not enough to provide a conclusive answer. One also needs to study angel influence to determine whether angels have achieved a position of dominance. To this end analysis of campaign dynamics provides further insights.

\subsection{Campaign dynamics}

The temporal funding dynamics suggest significant differences between successful and unsuccessful campaigns. As an example, we plot the progression curves (i.e., cumulative percentage of funding goal fulfilled) for a successful and an unsuccessful campaign with the same funding goal $(£ 100,000)$ and comparable number of pledges (Figures 7 and 8). Dots represent the percentage contribution per pledge considering the campaign goal, and the shaded area shows the cumulative percentage raised. The progression curve for the successful campaign shows several moments at which the curve rises sharply. These "jumps" correspond to high-contribution pledges. For simplicity, we will regard pledges accounting for more than $10 \%$ of the funding goal for a campaign as jumps (these pledges also correspond to the top $1 \%$ 
pledges in terms of percentage contribution). The successful campaign received three jump pledges contributing $35 \%, 10 \%$, and $20 \%$ of the goal. The progression curve for the unsuccessful campaign shows no jump pledges.

We observe a similar pattern for most successful and unsuccessful campaigns, suggesting jumps play a pivotal role in the success of campaigns. In general, successful campaigns had eight times more jump pledges compared to unsuccessful campaigns (3.54 vs. 0.46). However, these high-contribution pledges do not fulfil the entire funding needs for a successful campaign. On average jumps account for about $54.16 \%$ of a campaign's goal (median of $11.11 \%$ ). Hence, campaign success depends on pledges from more investors than only those associated with the high-contribution pledges.

We also observe that both the crowd and angel investors make jumps, but there is a concentration of angel jumps in larger campaigns. As a result, angels contribute more to the funding goal of large campaigns but the crowd also seems to be playing a fundamental role (see, Table 4).

Finally, a higher percentage of angel jumps in successful campaigns (vs. unsuccessful campaigns) took place during the public launch period (64\% vs. $46 \%)$, suggesting the importance of jump observability. However, the dynamics of inter-investor information flow are still unclear because we do not know when and how angel jumps influence a campaign's success. Understanding these dynamics will allow us to determine whether angels dominate the platform, reducing the influence of crowd investors, or whether the co-existence of angels and crowd investors provides significant benefits for investors and entrepreneurs.

\section{Empirical Analysis}

To study whether and how jumps, especially jump pledges by angels, influence the behavior of investors on this platform, we adopt a fixed effects lognormal model of pledge value:

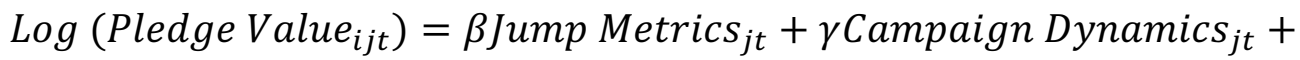

$$
\begin{aligned}
& \text { SInvestor Dynmaics }_{i t}+\theta \text { Campaign Attributes }_{j}+\mu_{i}+v_{t}+\epsilon_{i j t}
\end{aligned}
$$


The dependent variable Pledge Value $_{i j t}$ denotes the amount pledged by investor $i$ in campaign $j$ at investment occasion $t$, and Jump Metrics represents a vector of our independent variables. Campaign Dynamics, Investor Dynamics, and Campaign Attributes are vectors of control variables that reflect campaign- and investor-specific, time-variant and time-invariant features (we will specify below). The vectors of parameters $\beta, \gamma, \delta$, and $\theta$ correspond to model coefficients, $\mu_{i}$ captures investor-level fixed effects, $v_{t}$ includes yearly and day-of-week dummies, and $\epsilon_{i j t}$ represents independently and identically distributed normal error terms.

We created two independent variables: Jump Occurred and Angel Jump. Jump Occurred is an indicator variable equal to one once a campaign has received the first jump pledge, and zero any time before that, allowing us to test if a high-contribution pledge serves as a signal of campaign quality and whether it impacts subsequent investor behavior (H1). Angel Jump is an indicator variable equal to one if the most recent jump to a campaign is made by an angel with a visible profile, and zero otherwise, allowing us to test the impact of an angel-generated signal (H2). The value of Angel Jump is updated only when a new jump occurs.

We also included several control variables in our model. Because investors are likely to perceive jumps accounting for $90 \%$ versus $20 \%$ of a campaign goal differently, we included Jump Size as a control. This variable measures the percentage contribution to the funding goal of the most recent jump made to the campaign (it updates when a new jump occurs). Because the effect of a signal is likely to diminish over time (Estrin and Khavul, 2016), we included Jump Recency as an additional control that corresponds to the number of days passed since the most recent jump.

We also included linear and squared terms of Cumulative Percent Raised for each campaign to control for the (possibly non-linear) effect of a campaign's fundraising progress and investor herd behavior. Previous research has shown herd behavior can occur when campaigns are close to reaching their funding goal (Agrawal et al., 2014). Considering that investors monitor campaign's progression and accumulate knowledge (Hu and Gorbatai, 2015), 
follow-up investments in the same campaign are likely to differ from initial investments. Therefore, we included Investor Campaign Experience as an additional control that records the number of times an investor has previously invested in the campaign. To account for angels' sectoral experience and habitual investment behavior (Maula et al., 2005), we included Investor Sectoral Experience dummy (taking the value one if the investor has previously invested in campaigns of the same sector, and zero otherwise).

We also accounted for observed heterogeneity across investors by including control variables such as Investor Cumulative Amount Pledged (calculated across all campaigns) and Days Since Investor's Last Pledge (to account for investor-specific recency effects). We also controlled for the impact of entrepreneur- and campaign-related factors such as the percentage of equity offered to investors (Campaign Equity Offered), the effect of time pressure (Days Until Campaign Expiration), and the interaction between entrepreneurs and investors during the private launch period (Private Launch Pledge). Further, to control for competitive effects across campaigns we included Daily Number of Active Campaigns, which counts the number of active campaigns on the same day of the pledge. Finally, year-specific dummy variables and day-specific dummy variables were included to control for yearly trends, and day-specific factors, respectively.

\section{Results and Discussion}

\subsection{Results summary}

Table 5 (Models 1 through 6) and Table 6 (Models 7 through 10) present the main results. We report the results of the model with Jump Occurred $(J O)$ as the independent variable using the entire sample to test $H 1$ (Model 1), and a full model with Angel Jump (AJ) to test H2 (Model 2). We also estimate models for angels and crowd investors separately using standardized variables to test $H 3$ (Models 3 and 4). Finally, to test $H 4 a$ and $H 4 b$ we repeat the analysis with standardized variables but split the sample by campaign size (Models 5 and 6). We further report the four sub-models for angels and crowd investors in large and small campaigns (see 
Models 7 through 10).

Consistent with $H 1$, we find that a jump pledge positively affects the amount invested by subsequent investors (Model 1: $\beta_{J O}=0.127, p$-value $<0.001$ ). The increase is significant as investors pledge $13.5 \%\left(0.135=e^{0.127}-1\right)$ more in a campaign in which previously a jump pledge had occurred, compared to when no previous jump pledge was present. When the jump pledge in a campaign is from an angel investor, we observe an additional positive impact, even after controlling for the jump. If the jump pledge is from an angel investor subsequent pledges increase by an extra $6.0 \%$, supporting $H 2$ (Model 2: $\beta_{A J}=0.058, p$-value $\left.<0.001\right)$. We also note that the signaling effect of jumps decays over time as we find a negative effect of Jump Recency (Model 2: $\beta_{J R}=-0.003, p$-value $\left.<0.001\right)$.

We find that an angel jump increases the amount per pledge by $7.0 \%$ for angels and $5.5 \%$ for the crowd. To explore differences in behavior between angels and crowd investors we conducted split-sample analysis by investor type using standardized variables. We find that Angel Jump has a greater positive impact on angels compared to crowd investors (Model 3: $\beta_{A J}$ $=0.015, p$-value $=0.079$; versus Model 4: $\beta_{A J}=0.012$, $p$-value $\left.<0.001\right)$ supporting $H 3$ and suggesting angels react more positively to signals sent by their peers than by crowd investors.

Using standardized variables, split-sample analysis by campaign size shows that the positive effect of Angel Jump is significant in large campaigns (Model 5: $\beta_{A J}=0.009, p$ value $<0.001$ ) but insignificant in small campaigns (Model 6: $\beta_{A J}=0.003$, $p$-value $=0.460$ ). This supports the argument that investors perceive angel jumps as costly signals only in large campaigns, hence, influencing subsequent pledges. In contrast, angel jumps in small campaigns do not change subsequent pledge behavior, suggesting that lower valued jumps are not costly to replicate and hence not perceived as effective signals of campaign quality. These results support the signal costliness hypotheses $(H 4 a$ and $H 4 b)$.

Consistent with the results from the analysis based on the entire sample, in Models 5 and 6 our results suggest that the effect size of Angel Jump is greater in large campaigns than in 
small campaigns for all types of investors. We find that a previous angel jump increases subsequent pledges by $14.1 \%$ and $12.6 \%$ in large and small campaigns, respectively. In addition, the differences in beta coefficients for the models of investor type by campaign size confirm that Angel Jump has a greater impact in large campaigns (for angels compare Models 7: $\beta_{A J}=$ $0.030, p$-value $<0.001$ vs. Model 8: $\beta_{A J}=0.027, p$-value $=0.069 ;$ for the crowd compare Model 9: $\beta_{A J}=0.009, p$-value $<0.001$ vs. Model 10: $\beta_{A J}=-0.001, p$-value $\left.=0.843\right)$. Again, these results further support the signal costliness hypotheses ( $H 4 a$ and $H 4 b)$.

\subsection{Additional analyses and robustness checks}

\subsubsection{Alternative identification approach for angel investors}

We identified angels based on total amount invested on the platform, an approach that could potentially leave out angels not particularly active or who have joined the platform in a later period of the sample. For example, an inactive angel or an angel who joined the platform towards the end of the sample period might make a single large pledge but might not meet the top $1 \%$ total investment threshold. To account for such instances, we tested our hypotheses using alternative identification approaches (see Appendix, Table A1). We identified the top 1\% of investors considering three alternatives: (1) the value of the largest pledge, (2) the average value pledged per campaign, and (3) the average value per pledge. The alternative specifications classify 510, 509, and 510 investors as angels, respectively, with an overlap with the original classification of $67 \%, 70 \%$, and $78 \%$. Further, to ensure that we accurately capture offline angels, we also classified as angels those investors who have made at least one jump and one pledge in the private launch period. This resulted in 726 investors and a 54\% overlap with our original approach. We find that under all four alternative classification approaches Angel Jump has a positive and significant impact on subsequent pledges (see Models 11 to 14, Table A1). Hence, the impact of angel jumps is robust to the criteria used for angel identification.

\subsubsection{Alternative jump definition}

As an additional robustness check, we tested our hypotheses using an alternative jump 
definition that relies on absolute monetary value. In this scenario, we classify pledges greater than $£ 20,000.50$ (i.e., top $1 \%$ in terms of value per pledge) as jumps. Results with this alternative specification are again consistent with the main model results (see, Table A2).

\subsubsection{Follow-up investments}

Signal effectiveness could also depend on initial versus follow-up investments. We study follow-up investments using two approaches: firstly, we look at follow-up investments by an investor within the same campaign and, secondly, we evaluate differences in investments in ventures seeking initial versus higher rounds of financing. Although we controlled for followup investments in Models 1 through 10 (see, Tables 5 and 6) using the Investor Campaign Experience variable, here we provide an additional analysis using models estimated separately for different sample splits: initial investments versus follow-up investments.

We observe that 9,008 investors have made follow-up investments to the same campaign. We find Angel Jump having a greater impact on initial investments (Model 18: $\beta_{A J}=0.065, p$ value $<0.001$,) compared with follow-up investments to the same campaign (Model 19: $\beta_{A J}=$ 0.052, $p$-value $<0.001)$. As for ventures running multiple rounds of fundraising campaigns, ${ }^{4}$ we observe that 103 ventures have successfully raised funds from 223 campaigns. ${ }^{5} \mathrm{We}$ distinguished investments in initial and higher $(\geq 2)$ rounds and repeated our analysis. We find a stronger effect of Angel Jump on investments made to initial rounds (Model 20: $\beta_{A J}=0.083$, $p$-value $<0.001)$ compared to investments made to campaigns seeking additional rounds of financing (Model 21: $\beta_{A J}=0.046, p$-value $\left.<0.001\right)$.

Consistent with arguments that signals are more effective when information asymmetries are more severe (e.g., Chen et al., 2012), our results show that angel jumps have a stronger positive impact on investors pledging in initial versus follow-up investments.

\footnotetext{
${ }^{4}$ We also controlled for the impact of follow-up investments across multiple rounds of the same venture by including a dummy variable (Investor Previous Round Experience) indicating whether an investor had already invested in a previous round. We find that the impact of angel jumps on investment behavior is robust to the inclusion of the additional investment round control $\left(\beta_{A J}=0.054, p\right.$-value $\left.<0.001\right)$. Finally, models by investor type are also consistent with our overall results. Detailed results available from the authors upon request.

${ }^{5}$ We only focus on campaigns that were successful and reached their funding goal in more than one round.
} 


\subsubsection{Investor syndicating behavior}

Angels typically engage in co-investing and syndicating behavior (Mason et al., 2016). In our platform, angels who co-invest in the campaign's private launch period are more likely to build informal offline connections. These connections could provide an alternative explanation for the results we find and the role of ECF platforms in open and public information dissemination to be less important for the effects we find.

To test for these alternative explanations, we focus on 342 angels who pledged during the private launch and build a 342-by-342 adjacency matrix of whether two angels have coexisted in any campaign's private launch period or not. The density of this proxy network is very low (0.08), meaning that among the $58,311(342 * 341 / 2)$ potential angel pairs, only 4,722 engaged in co-investment in private launch periods, and $77 \%$ of these pairs co-invested only once. Therefore, our results indicate very limited evidence of (informal) syndication or offline networking. Instead the signaling effects occur due to the information flow between investors facilitated by the digital channel.

\subsection{Discussion}

The digitization of early-venture funding through ECF platforms provides the opportunity to close funding gaps by serving ventures that institutional investors are unwilling to consider. It facilitates the exchange between many common investors and entrepreneurs, overcoming the difficulties typically posed by offline channels, such as access to angels, physical distance and the lack of social capital. In the past years, the venture diversity (in sector and scale), the upside potential of early-stage ventures, and the convenience offered by ECF platforms have attracted sophisticated and professional investors such as business angels who now invest alongside small non-professional investors. The influx of large investors, although providing opportunities to entrepreneurs, could constitute a threat to the democratizing role of ECF platforms, if large investors crowd out smaller and non-professional ones. 
Our study sheds light on this issue and responds to a call for evidence-based research on the interaction between angels and the crowd (Hellmann and Thiele, 2015; Hornuf and Schwienbacher, 2016). To the best of our knowledge, ours is the first study to rely on investors' pledging decisions to empirically identify and categorize ECF investors, adding to the insights obtained through previous surveys and interviews (e.g., BBB and UKBAA, 2017).

Our results show that the growth of large campaigns and the presence of angel investors on the ECF platform go hand-in-hand. Angels invest in large campaigns and are essential to their success on the platform. Despite the growth in angel investors, we find crowd investors still play an important role in bridging funding gaps in large campaigns. For small campaigns that do not attract angel investments, crowd investors are instead the fundamental source of funding. This angel-crowd complementarity suggests that ECF has maintained its democratic credentials.

In addition, the presence of angels and the visibility of their funding behavior via digital ECF platforms help reduce information asymmetry in early-stage financing. Such asymmetries typically generate market frictions and inefficiencies. Angel's investment decisions, and specifically their high-contribution pledges, act as informative signals of venture quality. Hence, crowdfunding platforms facilitate information flow from more experienced, and possibly better-informed investors, to the crowd. In a context where regulators fear for the financial health of small non-professional investors, our results suggest that the digital environment of ECF platforms with real-time and fast-paced flows of information benefit novice investors as they can easily observe the investment behavior of angels.

Although a large body of ECF literature has explored the effects of entrepreneurgenerated signals on investor behavior (e.g., Ahlers et al., 2015), how investors interact and how information flows among investors is seldom studied. We provide an important contribution in this regard. We find that the digitization of venture financing has not only allowed entrepreneurs to communicate easily to a larger and more diverse group of investors, 
it has also allowed investors to observe the decisions of other investors, facilitating interinvestor information flow. Hence, the digitization of early stage finance has been able to reduce the limits imposed by the need for physical and social proximity.

Our work also addresses the call for multidisciplinary crowdfunding research (McKenny et al., 2017). We combine insights from information economics, sociology, and entrepreneurship to shed light on the impact of investor-generated signals on ECF platforms. Although our results are novel and contribute to signaling research in crowdfunding literature, they are also consistent with more general signaling theories of social proximity (e.g., Cowgill et al., 2009) and signal costliness (e.g., Connelly et al., 2011). For example, we demonstrate that information flow between investors depends on the identity of the signal sender, signal recipient, and context.

\section{Policy Implications}

The regulator's support and sympathetic approach towards digital ECF (globally and especially in the UK) has increased the flow of capital to early-stage ventures and facilitated innovation. As ECF platforms evolve and mature, concerns arise regarding the protection of the interests of small investors. While some contend that the U.S. regulatory framework for ECF provides little protection to small investors (Shiller, 2015), other suggest that the UK regulators are too "fintech friendly" and compromise stringency in assessing investor qualification (Zhang et al., 2015).

For example, in the UK, the current regulatory framework requires investor selfcertification as high-net-worth, sophisticated, or everyday (crowd) investors. In the ECF platform we study, we find that a quarter of investors self-certified as high-net-worth individuals invested less than $£ 500$ over the entire period, whereas $2 \%$ of those self-certified as “everyday investors" invested more than $£ 66,000$ (our threshold for angel identification). These

results raise concerns regarding the accuracy of the current investor self-assessment procedure of ECF platforms. It is necessary for regulators to ensure standardized information collection 
across platforms via in-depth questionnaires on investors' financial acumen, investment experience, qualifications, and wealth. More importantly, using the behavior-based investor categorization that we employ in the current study, platforms could better segment investors and facilitate information flow by making these categories visible to platform members. Further, there is a need to educate inexperienced investors regarding the risks of investing in early stage ventures. Currently, ECF platforms inform investors via "risk warning" pages, blogs, and forums. There is a need to better explain various types of risks and make risk warnings more visible on ECF platforms.

In addition, there is evidence that some entrepreneurs send false signals to the market by making anonymous large investment in their own ventures (Burtch et al., 2013). Not surprisingly, the FCA has recently raised concerns regarding insufficient information transparency on digital funding platforms and has proposed to refine its current regulations on crowdfunding sector (FCA, 2018). Indeed, signaling across investors plays a significant role on ECF platforms and anonymous high-contribution pledges could pose a risk to investors less able to verify investors' credentials. In light of these concerns, to protect investors in general and crowd investors in particular, we urge regulators to consider greater transparency and information disclosure on ECF platforms for large pledges above a certain threshold. Platforms could require investors pledging more than $10 \%$ of a campaign's funding goal to disclose their real identities (instead of usernames), professional social network information (e.g., LinkedIn or Crunchbase pages), or authenticated personal webpages.

Finally, considering that many successfully funded ventures on ECF platforms eventually fail (Signori and Vismara, 2016) there is a greater need for regulators to impose standardized due diligence procedures for platforms to protect all investors. Many ECF investors, including angels, rely on platforms to screen ventures. Although the FCA requires platforms to conduct due diligence, in practice the background checks are not standardized across platforms. With the growth in funding volume raised by ECF platforms, such lack of clarity is no longer 
desirable. Regulators ought to impose more rigorous and standardized risk assessment of ventures featured by ECF platforms. Our findings support FCA's recent focus on tightening the regulatory framework for platforms and the demand side (i.e., ventures) of the crowdfunding sector (FCA, 2018).

\section{Conclusion}

Our analysis of one of the UK's leading ECF platforms provides an optimistic outlook for the future of digital crowdfunding. With greater transparency and standardized regulation, we believe that digital crowdfunding platforms can continue to support the complementary coexistence of angels and the crowd, greatly facilitating early-stage finance.

Our study is not devoid of limitations. Even though the ECF platform we study is representative of other leading platforms, and we proposed a robust angel identification strategy based on pledging behavior, future research could study the generalizability of our findings across platforms and alternative identification strategies. In addition, future research could explore in more detail the type of angels attracted by ECF platforms and whether angels treat ECF as a different asset class. As ECF grows, we expect to see greater involvement of angels, providing more opportunities to study their behavior.

Prior research has found that ventures with angel investments have higher survival and growth rates (Kerr et al., 2011). Thus, from a practical and policy perspective, it is important to study whether the long-term performance of ventures funded by angels on ECF platforms mirrors that of ventures that obtain funding via conventional means of finance. Although we find no evidence of syndication, investors (particularly angels) may accumulate social capital through co-investments and form syndicates as the ECF market matures. Hence, future research could explore whether syndicates emerge on digital platforms. 
Table 1: Average Campaign Attributes by Campaign Size

\begin{tabular}{lrr}
\hline & $\begin{array}{c}\text { Large Campaigns } \\
(N=640)\end{array}$ & $\begin{array}{c}\text { Small Campaigns } \\
(N=511)\end{array}$ \\
\hline Pre-money Valuation $\left(£^{\prime} 000\right)$ & $4,429.28$ & 922.61 \\
Funding Goal (£'000) & 315.88 & 49.96 \\
Campaign Equity Offered (\%) & 12.54 & 10.46 \\
Number of Investors & 153.25 & 55.52 \\
Final Funded Rate & 0.88 & 1.09 \\
\hline
\end{tabular}

Table 2a: Comparison of Angel Behavioral Metrics

\begin{tabular}{lcc}
\hline & BBB \& UKBAA (2017)* & Current Study \\
\hline Median Value of Investments (£) & 45,000 & 80,000 \\
Median Number of Investments Made & 2 & 1 \\
Percentage Invested in 1-5 Companies & $79 \%$ & $83 \%$ \\
Percentage Invested in 10+ Companies & $7 \%$ & $6 \%$ \\
Percentage Located in London & $35 \%$ & $40 \%$ \\
Percentage Invested in ICT/Digital Tech Sector & $81 \%$ & $82 \%$ \\
\hline
\end{tabular}

*All figures obtained and calculated from angel investment metrics in 2016 as reported by BBB\&UKBAA

Table 2b: Comparison of Private- and Public-Only Angels

\begin{tabular}{|c|c|c|c|}
\hline (mean values reported) & $\begin{array}{r}\text { Private-Only } \\
\begin{array}{r}\text { Angels } \\
(N=82)\end{array} \\
\end{array}$ & $\begin{array}{r}\text { Public-Only } \\
\text { Angels } \\
(N=168) \\
\end{array}$ & p-value* \\
\hline Total Amount Invested (£) & 253,276 & 387,141 & 0.34 \\
\hline Average Amount Invested per Campaign (£) & 117,370 & 146,937 & 0.25 \\
\hline Number of Campaigns Invested & 1.99 & 1.43 & 0.24 \\
\hline Percentage of Investments in Large Campaigns & 0.94 & 0.95 & 0.73 \\
\hline Average Percentage Contribution per Pledge & 0.22 & 0.30 & 0.08 \\
\hline
\end{tabular}


Table 3: Average Investor Level Metrics by Type

\begin{tabular}{|c|c|c|}
\hline & $\begin{array}{r}\text { Angel Investors } \\
(N=510)\end{array}$ & $\begin{array}{r}\text { Crowd Investors } \\
(N=50,489)\end{array}$ \\
\hline Total Amount Pledged (£) & 254,707 & 2,110 \\
\hline Total Amount Pledged to Large Campaigns ( $($ ) & 239,783 & 1,831 \\
\hline Average Amount Invested per Campaign (£) & 142,862 & 1,401 \\
\hline Number of Pledges Made & 18 & 3 \\
\hline Number of Pledges Made to Large Campaigns & 13 & 2 \\
\hline Number of Campaigns Invested & 11 & 2 \\
\hline Number of Days since Registration with the Platform & 362 & 89 \\
\hline
\end{tabular}

Table 4: Summary Statistics on Jump Pledges

\begin{tabular}{lcc}
\hline & $\begin{array}{c}\text { Succesful Campaigns } \\
(N=456)\end{array}$ & $\begin{array}{c}\text { Failed Campaigns } \\
(N=695)\end{array}$ \\
\hline Number of Jump Pledges per Campaign & 3.54 & 0.46 \\
Total Contribution of Jump Pledges per Campaign & 0.72 & 0.08 \\
\hline & $\begin{array}{c}\text { Angel Jumps } \\
(N=823)\end{array}$ & $\begin{array}{c}\text { Crowd Jumps } \\
(N=1,111)\end{array}$ \\
\hline Share of Jumps Associated with Large Campaigns & 0.74 & 0.41 \\
Average Size of Jumps* & 0.47 & 0.21 \\
Average Size of Jumps in Large Campaigns* & 0.33 & 0.15 \\
\hline
\end{tabular}

*Measured as share of contribution to campaign funding goal 
Table 5: Results

\begin{tabular}{|c|c|c|c|c|c|c|}
\hline & $\begin{array}{l}\text { Model } 1 \\
\text { Pooled }\end{array}$ & $\begin{array}{l}\text { Model } 2 \\
\text { Pooled }\end{array}$ & $\begin{array}{l}\text { Model } 3 \\
\text { Angel }\end{array}$ & $\begin{array}{l}\text { Model } 4 \\
\text { Crowd }\end{array}$ & $\begin{array}{c}\text { Model } 5 \\
\text { Large } \\
\text { Campaign }\end{array}$ & $\begin{array}{c}\text { Model } 6 \\
\text { Small } \\
\text { Campaign }\end{array}$ \\
\hline \multirow[t]{2}{*}{ Angel Jump } & & $0.058 * * *$ & $0.015^{*}$ & $0.012 * * *$ & $0.009 * * *$ & 0.003 \\
\hline & & $(0.008)$ & $(0.009)$ & $(0.002)$ & $(0.002)$ & $(0.004)$ \\
\hline \multirow[t]{2}{*}{ Jump Occurred } & $0.127 * * *$ & $0.111 * * *$ & $0.111 * * *$ & $0.020 * * *$ & $0.015 * * *$ & $0.045 * * *$ \\
\hline & $(0.009)$ & $(0.009)$ & $(0.011)$ & $(0.002)$ & $(0.003)$ & $(0.004)$ \\
\hline \multirow[t]{2}{*}{ Jump Size } & -0.004 & -0.004 & -0.008 & -0.001 & -0.004 & -0.002 \\
\hline & $(0.004)$ & $(0.004)$ & $(0.008)$ & $(0.002)$ & $(0.006)$ & $(0.002)$ \\
\hline \multirow[t]{2}{*}{ Jump Recency } & $-0.003 * * *$ & $-0.003 * * *$ & $-0.066 * * *$ & $-0.018 * * *$ & $-0.020 * * *$ & $-0.013 * * *$ \\
\hline & $(0.0002)$ & $(0.0002)$ & $(0.010)$ & $(0.002)$ & $(0.002)$ & $(0.004)$ \\
\hline \multirow{2}{*}{$\begin{array}{l}\text { Cumulative Percent } \\
\text { Raised }\end{array}$} & $-0.013 * * *$ & $-0.015 * * *$ & $-0.132 * * *$ & -0.003 & $0.024 * *$ & -0.004 \\
\hline & $(0.005)$ & $(0.005)$ & $(0.021)$ & $(0.004)$ & $(0.009)$ & $(0.008)$ \\
\hline \multirow{2}{*}{$\begin{array}{l}\text { Squared Cumulative } \\
\text { Percent Raised }\end{array}$} & 0.0002 & $0.0002 *$ & $0.109 * * *$ & -0.002 & $-0.311 * * *$ & 0.001 \\
\hline & $(0.0001)$ & $(0.0001)$ & $(0.020)$ & $(0.004)$ & $(0.054)$ & $(0.007)$ \\
\hline \multirow{2}{*}{$\begin{array}{l}\text { Days Until Campaign } \\
\text { Expiration }\end{array}$} & $0.039 * * *$ & $0.039 * * *$ & $0.043 * * *$ & $0.031 * * *$ & $0.036^{* * *}$ & $0.021 * * *$ \\
\hline & $(0.003)$ & $(0.003)$ & $(0.014)$ & $(0.003)$ & $(0.003)$ & $(0.005)$ \\
\hline \multirow{2}{*}{$\begin{array}{l}\text { Campaign Equity } \\
\text { Offered }\end{array}$} & -0.003 & -0.006 & $0.041 * * *$ & $-0.006^{* * *}$ & $-0.025^{* * *}$ & $0.024 * * *$ \\
\hline & $(0.006)$ & $(0.006)$ & $(0.011)$ & $(0.002)$ & $(0.003)$ & $(0.004)$ \\
\hline Private Launch Pledge & $\begin{array}{c}0.122 * * * \\
(0.013)\end{array}$ & $\begin{array}{c}0.116^{* * *} \\
(0.013)\end{array}$ & $\begin{array}{c}0.003 \\
(0.013)\end{array}$ & $\begin{array}{c}0.028 * * * \\
(0.003)\end{array}$ & $\begin{array}{c}0.035 * * * \\
(0.004)\end{array}$ & $\begin{array}{c}-0.015^{* * *} \\
(0.006)\end{array}$ \\
\hline \multirow{2}{*}{$\begin{array}{l}\text { Daily Number of } \\
\text { Active Campaigns }\end{array}$} & $-0.001^{*}$ & $-0.001 *$ & 0.020 & $-0.007 * * *$ & $-0.007 * *$ & $-0.018 * * *$ \\
\hline & $(0.0007)$ & $(0.0007)$ & $(0.012)$ & $(0.003)$ & $(0.003)$ & $(0.005)$ \\
\hline \multirow[t]{2}{*}{$\begin{array}{l}\text { Days since Investor's } \\
\text { Last Pledge }\end{array}$} & $0.046 * * *$ & $0.045 * * *$ & $0.058 * * *$ & $0.043 * * *$ & $0.048 * * *$ & $0.028 * * *$ \\
\hline & $(0.002)$ & $(0.002)$ & $(0.011)$ & $(0.002)$ & $(0.002)$ & $(0.004)$ \\
\hline \multirow{2}{*}{$\begin{array}{l}\text { Investor Cumulative } \\
\text { Amount Pledged }\end{array}$} & $-0.061 * * *$ & $-0.061 * * *$ & -0.019 & $-0.133 * * *$ & $-0.126^{* * *}$ & $-0.085^{* * *}$ \\
\hline & $(0.002)$ & $(0.002)$ & $(0.016)$ & $(0.003)$ & $(0.004)$ & $(0.007)$ \\
\hline \multirow{2}{*}{$\begin{array}{l}\text { Investor Campaign } \\
\text { Experience }\end{array}$} & $0.243 * * *$ & $0.242 * * *$ & $0.060 * * *$ & $0.059 * * *$ & $0.059 * * *$ & $0.027 * * *$ \\
\hline & $(0.008)$ & $(0.008)$ & $(0.007)$ & $(0.002)$ & $(0.003)$ & $(0.004)$ \\
\hline \multirow{2}{*}{$\begin{array}{l}\text { Investor Sectoral } \\
\text { Experience }\end{array}$} & $0.030 * * *$ & $0.030 * * *$ & $0.025^{* *}$ & $0.012 * * *$ & $0.016 * * *$ & -0.006 \\
\hline & $(0.005)$ & $(0.005)$ & $(0.010)$ & $(0.002)$ & $(0.003)$ & $(0.004)$ \\
\hline Observations & 144,890 & 144,890 & 8,492 & 136,398 & 112,394 & 32,496 \\
\hline $\mathrm{BIC}$ & $339,913.900$ & $339,850.500$ & $17,857.510$ & $132,671.000$ & $121,996.300$ & $23,372.360$ \\
\hline
\end{tabular}


Table 6: Results by Investor Type and Campaign Size

\begin{tabular}{|c|c|c|c|c|}
\hline & $\begin{array}{c}\text { Model } 7 \\
\text { Angel } \\
\text { Large } \\
\text { Campaign } \\
\end{array}$ & $\begin{array}{c}\text { Model } 8 \\
\text { Angel } \\
\text { Small } \\
\text { Campaign } \\
\end{array}$ & $\begin{array}{c}\text { Model } 9 \\
\text { Crowd } \\
\text { Large } \\
\text { Campaign } \\
\end{array}$ & $\begin{array}{c}\text { Model } 10 \\
\text { Crowd } \\
\text { Small } \\
\text { Campaign } \\
\end{array}$ \\
\hline Angel Jump & $\begin{array}{l}0.030 * * * \\
(0.011)\end{array}$ & $\begin{array}{l}0.027 * \\
(0.015)\end{array}$ & $\begin{array}{c}0.009 * * * \\
(0.002)\end{array}$ & $\begin{array}{l}-0.001 \\
(0.005)\end{array}$ \\
\hline Jump Occurred & $\begin{array}{c}0.454 * * * \\
(0.031)\end{array}$ & $\begin{array}{c}0.074 * * * \\
(0.014)\end{array}$ & $\begin{array}{l}0.005 * \\
(0.003)\end{array}$ & $\begin{array}{c}0.041^{* * * *} \\
(0.004)\end{array}$ \\
\hline Jump Size & $\begin{array}{l}-0.021 \\
(0.030)\end{array}$ & $\begin{array}{l}-0.006 \\
(0.007)\end{array}$ & $\begin{array}{l}-0.003 \\
(0.006)\end{array}$ & $\begin{array}{l}-0.001 \\
(0.002)\end{array}$ \\
\hline Jump Recency & $\begin{array}{c}-0.043 * * * \\
(0.014)\end{array}$ & $\begin{array}{c}-0.040 * * * \\
(0.015)\end{array}$ & $\begin{array}{c}-0.016^{* * *} \\
(0.002)\end{array}$ & $\begin{array}{c}-0.010^{* *} \\
(0.004)\end{array}$ \\
\hline Cumulative Percent Raised & $\begin{array}{c}-0.226 * * * \\
(0.053)\end{array}$ & $\begin{array}{l}-0.001 \\
(0.028)\end{array}$ & $\begin{array}{c}0.051 * * * \\
(0.009)\end{array}$ & $\begin{array}{l}-0.003 \\
(0.009)\end{array}$ \\
\hline Squared Cumulative Percent Raised & $\begin{array}{c}0.744 * * \\
(0.354)\end{array}$ & $\begin{array}{c}0.004 \\
(0.025)\end{array}$ & $\begin{array}{c}-0.417 * * * \\
(0.053)\end{array}$ & $\begin{array}{c}0.00008 \\
(0.007)\end{array}$ \\
\hline Days Until Campaign Expiration & $\begin{array}{c}0.051 * * * \\
(0.018)\end{array}$ & $\begin{array}{c}0.050 * * * \\
(0.017)\end{array}$ & $\begin{array}{c}0.037 * * * \\
(0.003)\end{array}$ & $\begin{array}{c}0.018^{* * * *} \\
(0.005)\end{array}$ \\
\hline Campaign Equity Offered & $\begin{array}{l}-0.006 \\
(0.014)\end{array}$ & $\begin{array}{c}0.056^{* * *} \\
(0.015)\end{array}$ & $\begin{array}{c}-0.026 * * * \\
(0.003)\end{array}$ & $\begin{array}{c}0.020 * * * \\
(0.004)\end{array}$ \\
\hline Private Launch Pledge & $\begin{array}{l}-0.007 \\
(0.016)\end{array}$ & $\begin{array}{l}-0.019 \\
(0.018)\end{array}$ & $\begin{array}{c}0.038 * * * \\
(0.004)\end{array}$ & $\begin{array}{c}-0.013 * * \\
(0.006)\end{array}$ \\
\hline Daily Number of Active Campaigns & $\begin{array}{c}0.024 \\
(0.016)\end{array}$ & $\begin{array}{c}0.006 \\
(0.017)\end{array}$ & $\begin{array}{c}-0.010 * * * \\
(0.003)\end{array}$ & $\begin{array}{c}-0.021 * * * \\
(0.005)\end{array}$ \\
\hline Days since Investor's Last Pledge & $\begin{array}{c}0.052 * * * \\
(0.014)\end{array}$ & $\begin{array}{c}0.055 * * * \\
(0.017)\end{array}$ & $\begin{array}{c}0.048 * * * \\
(0.002)\end{array}$ & $\begin{array}{c}0.027^{* * * *} \\
(0.004)\end{array}$ \\
\hline Investor Cumulative Amount Pledged & $\begin{array}{c}0.005 \\
(0.019)\end{array}$ & $\begin{array}{l}-0.050 \\
(0.031)\end{array}$ & $\begin{array}{c}-0.135 * * * \\
(0.004)\end{array}$ & $\begin{array}{c}-0.090 * * * \\
(0.007)\end{array}$ \\
\hline Investor Campaign Experience & $\begin{array}{c}0.082 * * * \\
(0.010)\end{array}$ & $\begin{array}{c}0.011 \\
(0.009)\end{array}$ & $\begin{array}{c}0.056^{* * *} \\
(0.003)\end{array}$ & $\begin{array}{c}0.034 * * * \\
(0.004)\end{array}$ \\
\hline Investor Sectoral Experience & $\begin{array}{c}0.036 * * * \\
(0.013)\end{array}$ & $\begin{array}{l}-0.001 \\
(0.013)\end{array}$ & $\begin{array}{c}0.015 * * * \\
(0.003)\end{array}$ & $\begin{array}{l}-0.007 * \\
(0.004)\end{array}$ \\
\hline $\begin{array}{l}\text { Observations } \\
\text { BIC }\end{array}$ & $\begin{array}{c}5,859 \\
12,773.250\end{array}$ & $\begin{array}{c}2,633 \\
4,133.809\end{array}$ & $\begin{array}{c}106,535 \\
102,732.500\end{array}$ & $\begin{array}{c}29,863 \\
18,010.440\end{array}$ \\
\hline
\end{tabular}


Figure 1: Monthly Amount Pledged by All Investors

(July 2012 to August 2017)

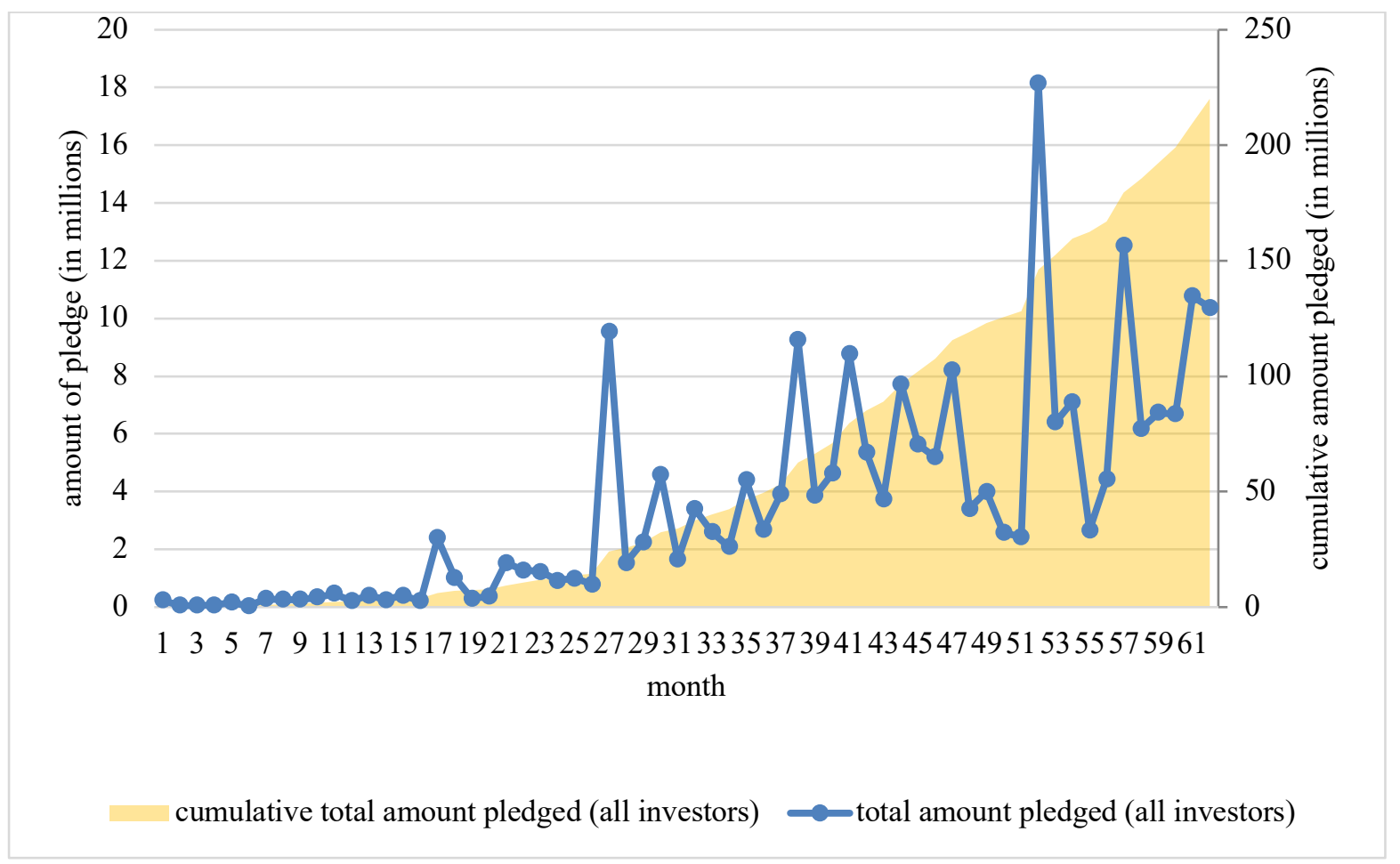

Figure 2: Monthly Number of Pledges by All Investors (July 2012 to August 2017)

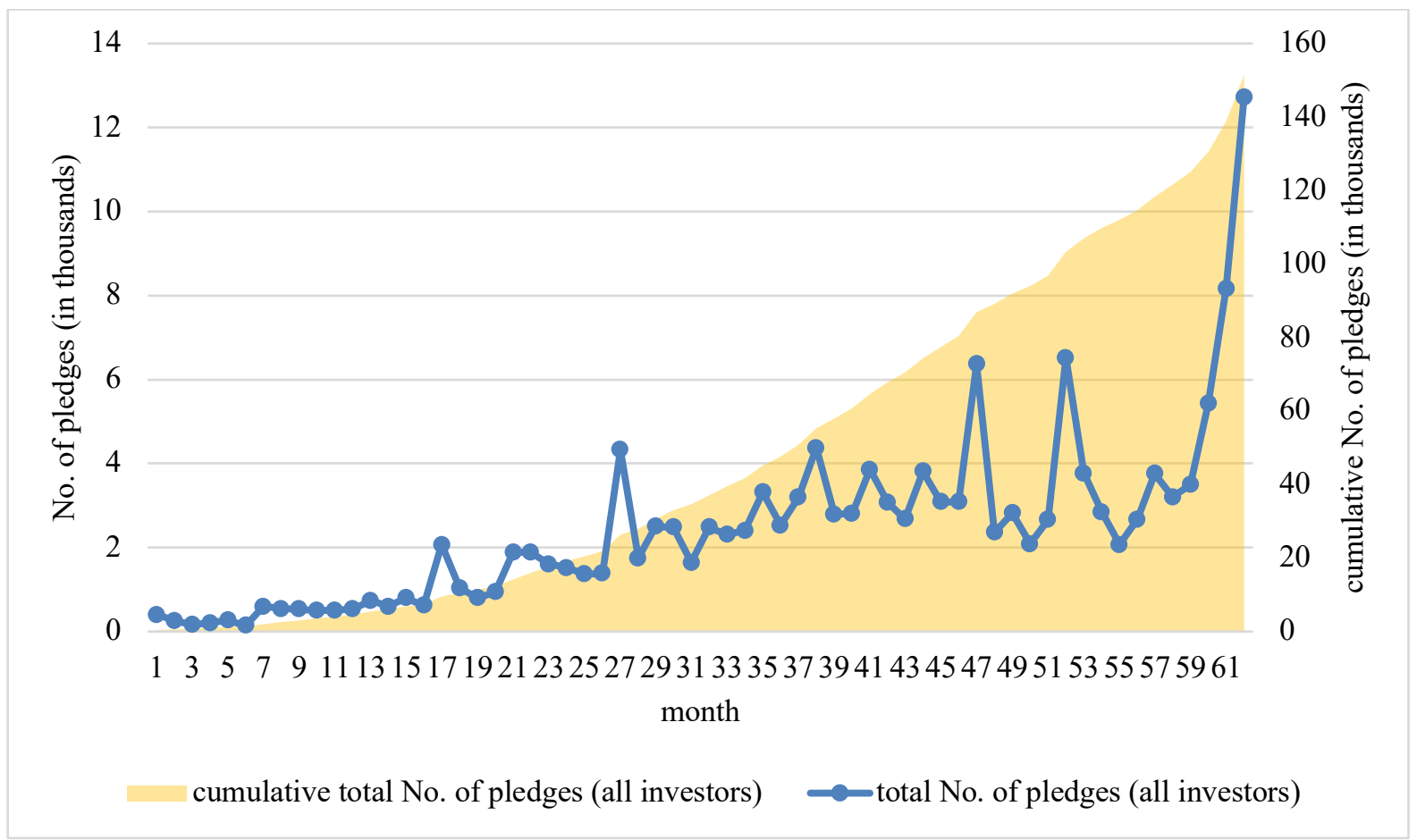


Figure 3: Monthly Number of Newly Added Campaigns by Size with Fitted Trends

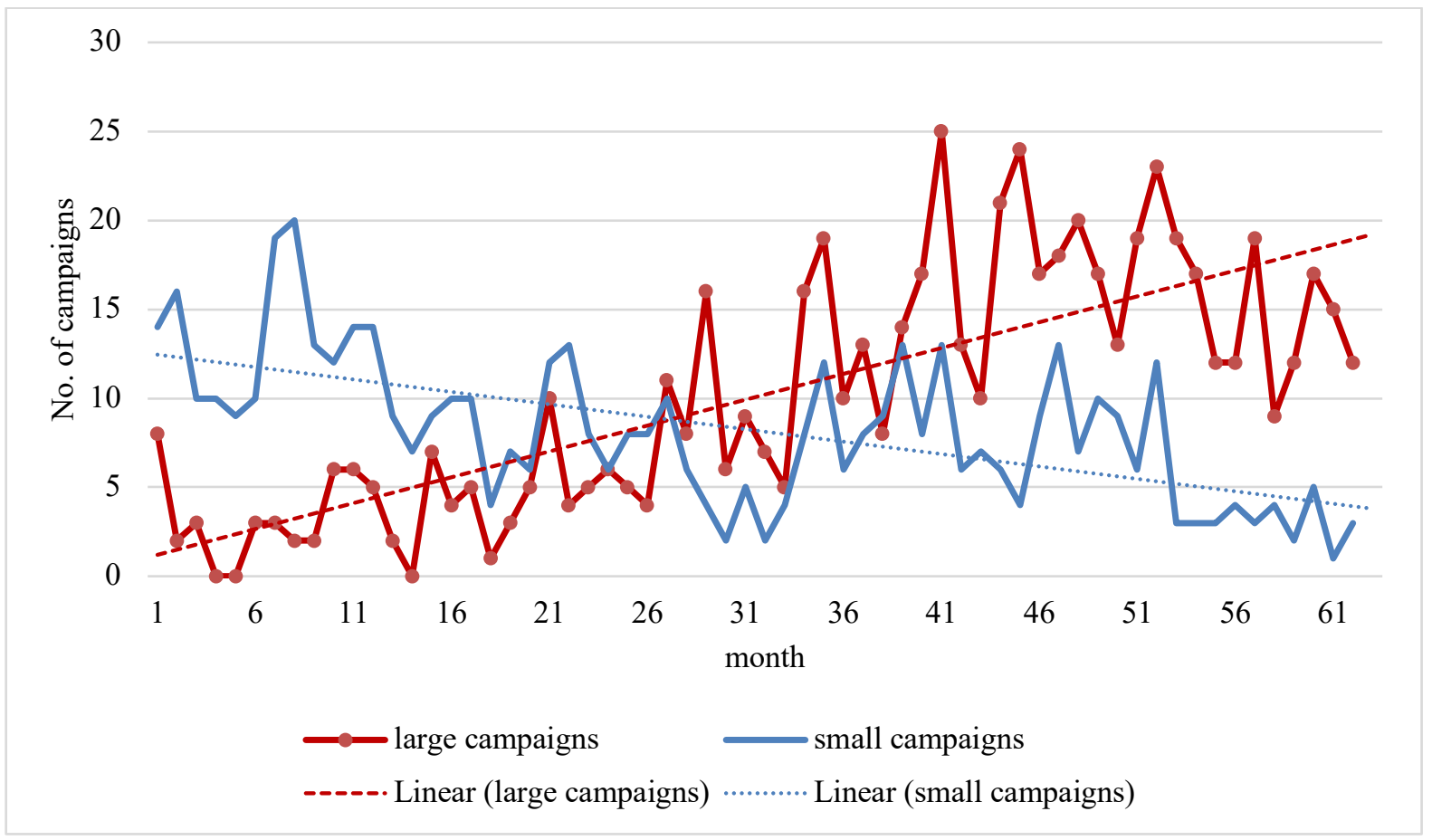

Figure 4: Monthly Number of Successful Campaigns by Size with Fitted Trends

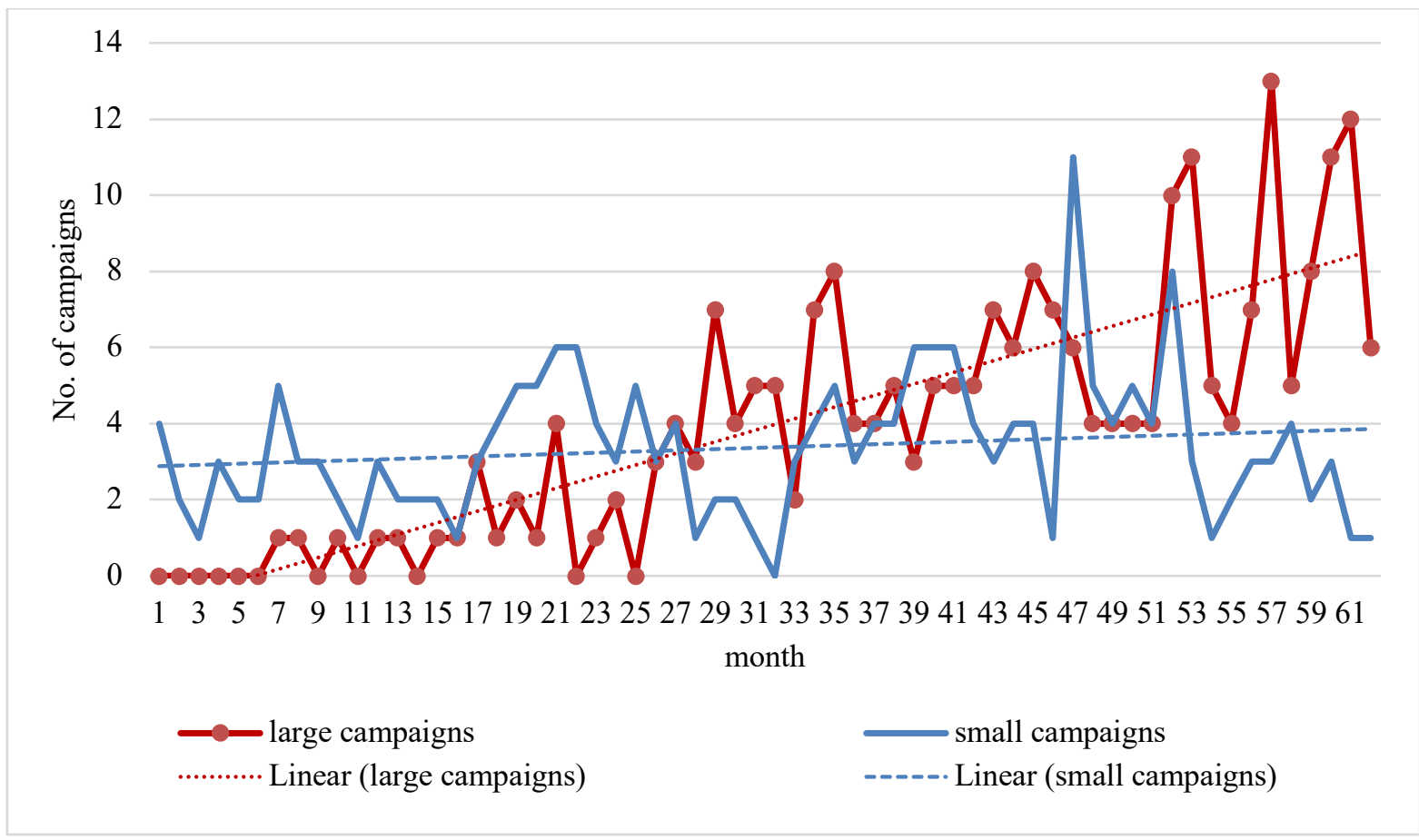


Figure 5: Number of Newly Joined Investors by Type and Month with Fitted Trends

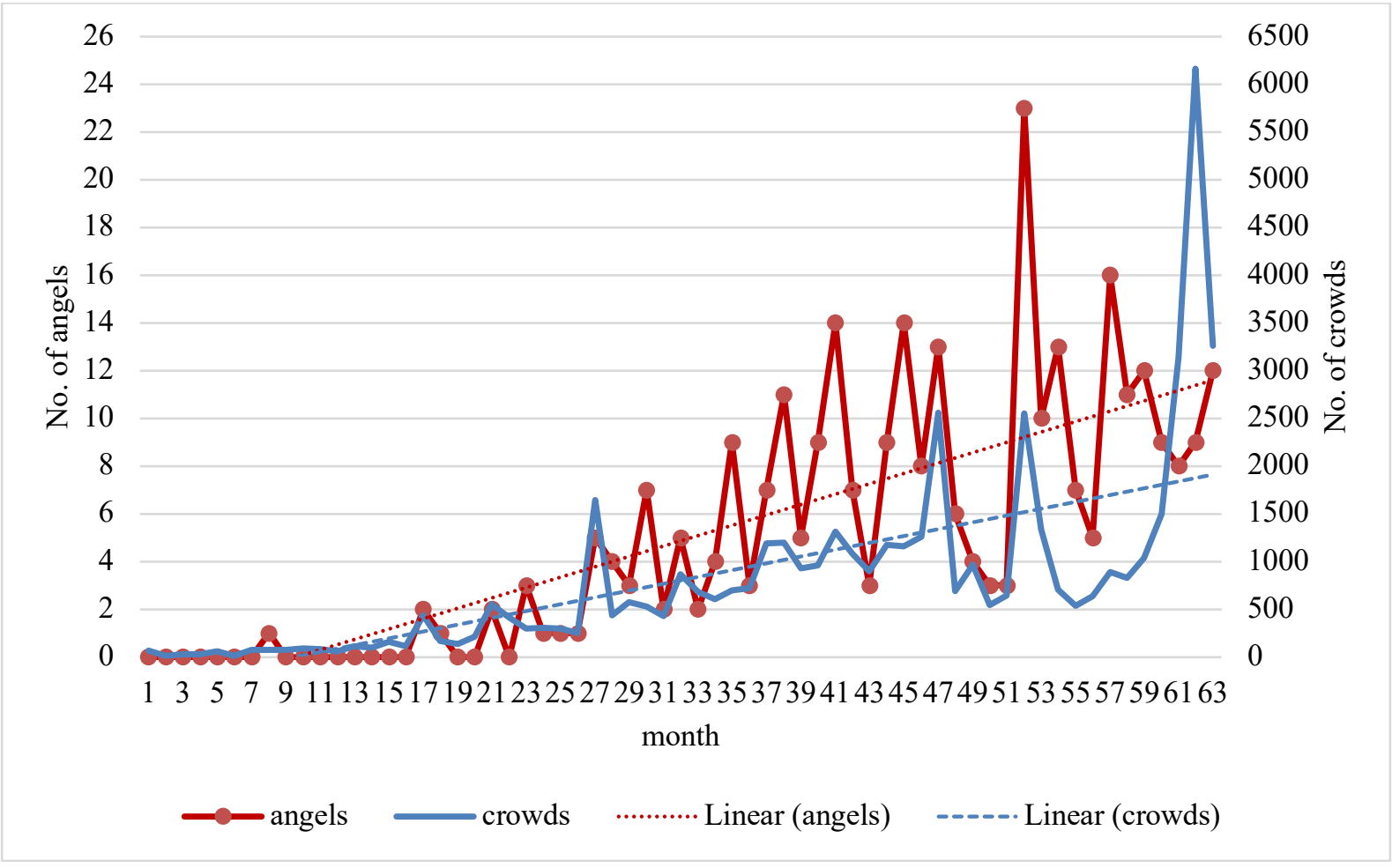

Figure 6: Average Size of Pledges by Investor Type and Month with Fitted Trends

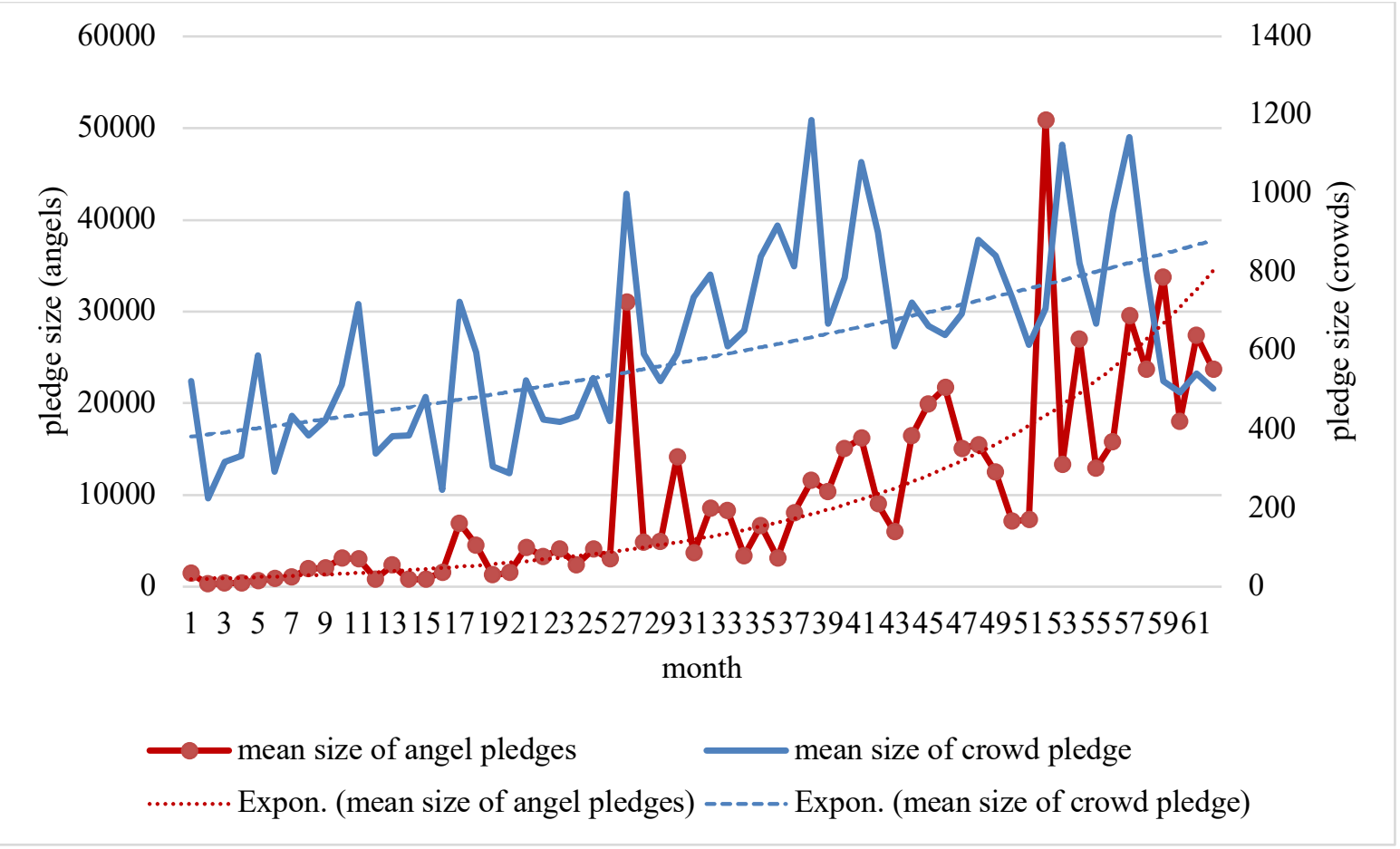




\section{Figure 7: Campaign Progression for a Successful Campaign}

(the campaign reached $129 \%$ of the $£ 100,000$ goal with three pledges contributing $\geq 10 \%$ )

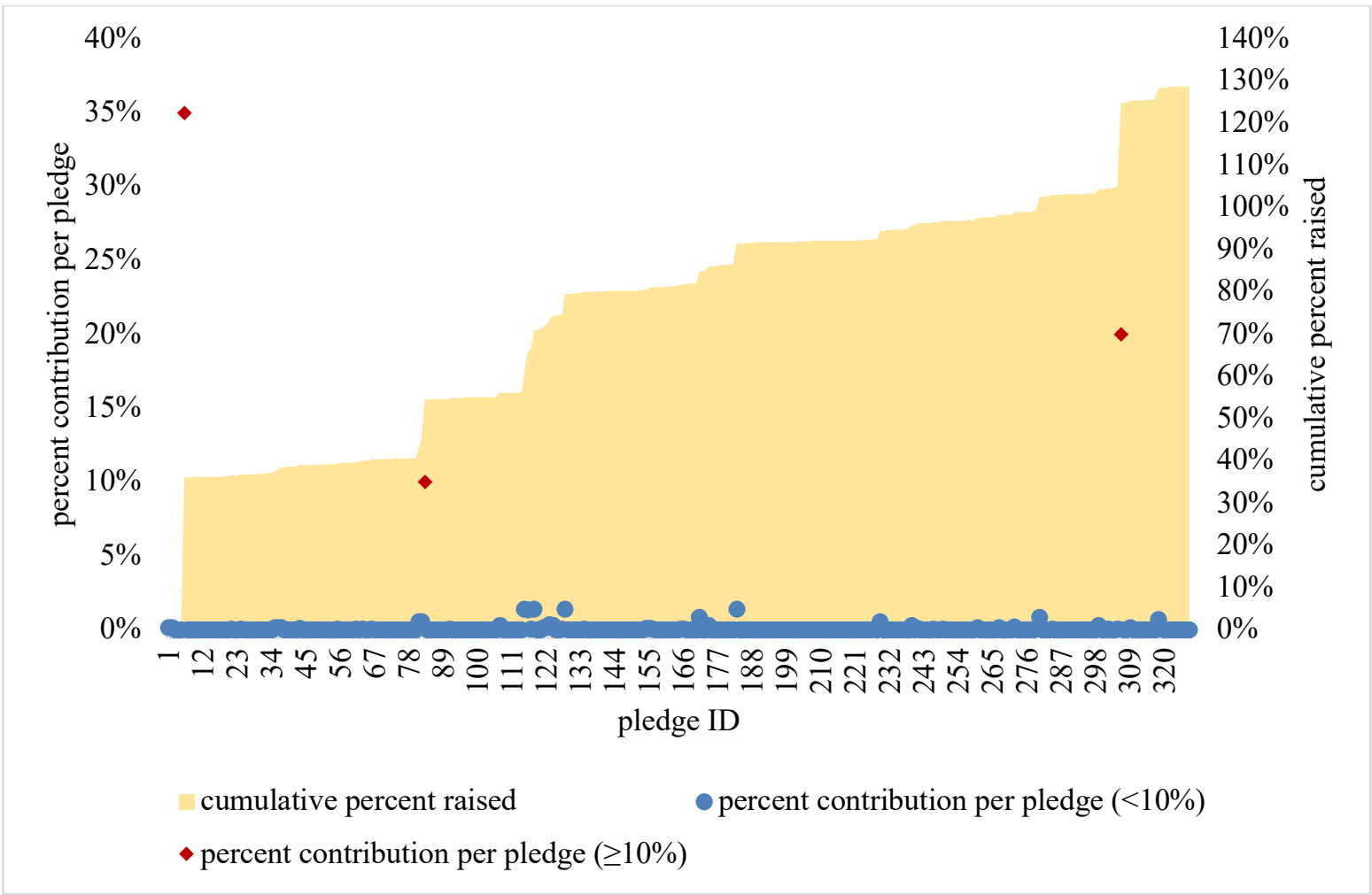

Figure 8: Campaign Progression for an Unsuccessful Campaign

(the camapign reached $74 \%$ of the $£ 100,000$ goal without any single pledge contributing $\geq 10 \%$ )

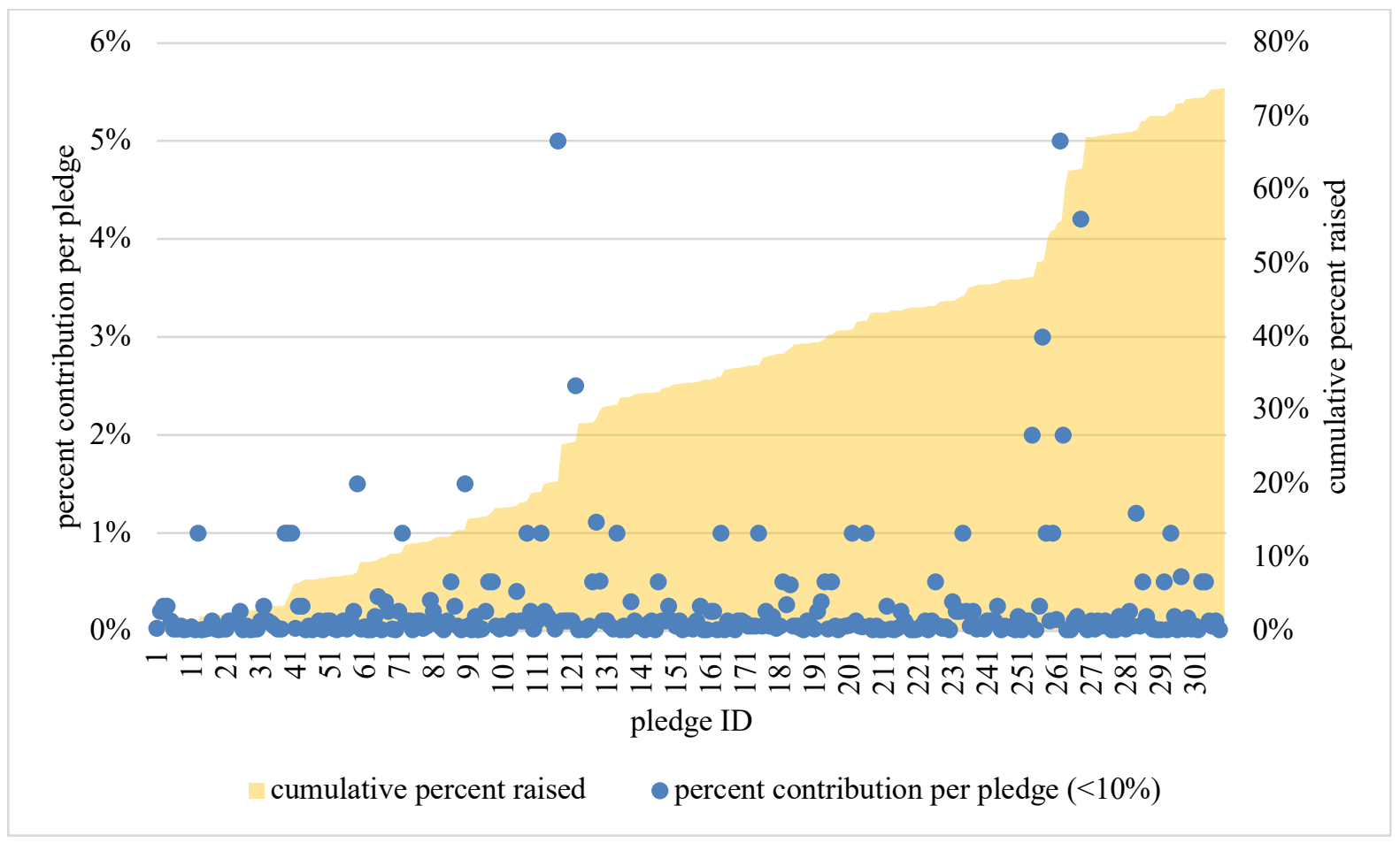




\section{APPENDIX: ROBUSTNESS CHECKS}

Table A1: Alternative Angel and Jump Identification

\begin{tabular}{|c|c|c|c|c|c|}
\hline & $\begin{array}{c}\text { Model } 11 \\
\text { Alternative } \\
\text { Angel } 1\end{array}$ & $\begin{array}{c}\text { Model } 12 \\
\text { Alternative } \\
\text { Angel } 2\end{array}$ & $\begin{array}{c}\text { Model 13 } \\
\text { Alternative } \\
\text { Angel 3 }\end{array}$ & $\begin{array}{c}\text { Model } 14 \\
\text { Alternative } \\
\text { Angel } 4\end{array}$ & $\begin{array}{c}\text { Model } 15 \\
\text { Alternative } \\
\text { Jump }\end{array}$ \\
\hline \multirow[t]{2}{*}{ Angel Jump } & $0.146^{* * *}$ & $0.171 * * *$ & $0.141 * * *$ & $0.027 * * *$ & $0.104 * * *$ \\
\hline & $(0.009)$ & $(0.008)$ & $(0.008)$ & $(0.008)$ & $(0.009)$ \\
\hline \multirow[t]{2}{*}{ Jump Occurred } & $0.023^{* *}$ & $0.044 * * *$ & $0.057 * * *$ & $0.111 * * *$ & $1.443 * * *$ \\
\hline & $(0.011)$ & $(0.010)$ & $(0.010)$ & $(0.010)$ & $(0.054)$ \\
\hline Control Variables Included & YES & YES & YES & YES & YES \\
\hline Observations & 144,890 & 144,890 & 144,890 & 144,890 & 144,890 \\
\hline $\mathrm{BIC}$ & $399,915.500$ & $399,714.200$ & $399,993.000$ & $339,908.800$ & $398,057.900$ \\
\hline
\end{tabular}

Table A2: Follow-up Investments

\begin{tabular}{|c|c|c|c|c|}
\hline & $\begin{array}{l}\text { Model } 18 \\
\text { Initial }\end{array}$ & $\begin{array}{l}\text { Model } 19 \\
\text { Follow-up }\end{array}$ & $\begin{array}{l}\text { Model } 20 \\
\text { Initial }\end{array}$ & $\begin{array}{l}\text { Model } 21 \\
\text { Follow-up }\end{array}$ \\
\hline Angel Jump & $\begin{array}{c}0.065 * * \\
(0.030)\end{array}$ & $\begin{array}{c}0.052 * * \\
(0.023)\end{array}$ & $\begin{array}{c}0.083 * * * \\
(0.008)\end{array}$ & $\begin{array}{c}0.046^{* * *} \\
(0.011)\end{array}$ \\
\hline Jump Occurred & $\begin{array}{c}0.104 * * * \\
(0.015)\end{array}$ & $\begin{array}{c}0.078^{* * *} \\
(0.013)\end{array}$ & $\begin{array}{c}0.041 * * * \\
(0.013)\end{array}$ & $\begin{array}{c}0.176^{* * *} \\
(0.014)\end{array}$ \\
\hline Control Variables Included & YES & YES & YES & YES \\
\hline Observations & 20,431 & 32,507 & 22,131 & 17,411 \\
\hline $\mathrm{BIC}$ & $36,432.290$ & $77,245.790$ & $40,393.640$ & $39,869.220$ \\
\hline
\end{tabular}




\section{References}

Agrawal, A., Catalini, C., \& Goldfarb, A. (2014). Some simple economics of crowdfunding. Innovation Policy and the Economy, 14(1), 63-97.

Agrawal, A., Catalini, C., \& Goldfarb, A. (2016). Are syndicates the killer app of equity crowdfunding?. California management review, 58(2), 111-124.

Ahlers, G. K., Cumming, D., Günther, C. \& Schweizer, D. (2015). Signaling in equity crowdfunding. Entrepreneurship Theory and Practice, 39, 955-980.

AIG. (2016). Considering potential risks and liabilities as the industry grows and matures. https://www.aig.co.uk/content/dam/aig/emea/united-kingdom/documents/Insights/equitycrowdfunding-thought-leadership-oct16.pdf

Beauhurst. (2017). The Deal, Equity investment in the UK 2017.

Belleflamme, P., Lambert, T., \& Schwienbacher, A. (2013). Individual crowdfunding practices. Venture Capital, 15(4), 313-333.

Bernstein, S., Lerner, J., Sorensen, M., \& Strömberg, P. (2016). Private equity and industry performance. Management Science, 63(4), 1198-1213.

Block, J., Hornuf, L., \& Moritz, A. (2018). Which updates during an equity crowdfunding campaign increase crowd participation?. Small Business Economics, 50(1), 3-27.

Brack, A. D., \& Benkenstein, M. (2012). The effects of overall similarity regarding the customer-to-customer-relationship in a service context. Journal of Retailing and Consumer Services, 19(5), 501-509.

British Business Bank \& UK Business Angel Association. (2017) Business Angel Spotlight.

Burtch, G., Ghose, A., \& Wattal, S. (2013). An empirical examination of users' information hiding in a crowdfunding context.

Chen, Y., Liu, Y., \& Zhang, J. (2012). When do third-party product reviews affect firm value and what can firms do? The case of media critics and professional movie reviews. Journal of Marketing, 76(2), 116-134.

Connelly, B. L., Certo, S. T., Ireland, R. D. \& Reutzel, C. R. (2011). Signaling theory: A review and assessment. Journal of Management, 37, 39-67.

Courtney, C., Dutta, S. \& Li, Y. (2017). Resolving information asymmetry: Signaling, endorsement, and crowdfunding success. Entrepreneurship Theory and Practice, 41, 265 290.

Cowgill, B., Wolfers, J., \& Zitzewitz, E. (2009). Using Prediction Markets to Track Information Flows: Evidence from Google. In AMMA (p. 3).

Drover, W., Busenitz, L., Matusik, S., Townsend, D., Anglin, A., \& Dushnitsky, G. (2017). A review and road map of entrepreneurial equity financing research: venture capital, 
corporate venture capital, angel investment, crowdfunding, and accelerators. Journal of Management, 43(6), 1820-1853.

Erikson, T., Sørheim, R., \& Reitan, B. (2003). Family angels vs. other informal investors. Family Business Review, 16(3), 163-171.

Estrin, S., \& Khavul, S. (2016). Equity crowdfunding: a new model for financing entrepreneurship? (No. 462). Centre for Economic Performance, LSE.

FCA (2018). FCA proposes changes to rules for crowdfunding platforms.

https://www.fca.org.uk/news/press-releases/fca-proposes-changes-rules-crowdfundingplatforms [last accessed 08/11/2018]

Gomulya, D., \& Mishina, Y. (2017). Signaler credibility, signal susceptibility, and relative reliance on signals: How stakeholders change their evaluative processes after violation of expectations and rehabilitative efforts. Academy of Management Journal, 60(2), 554-583.

Greenberg, J., \& Mollick, E. (2017). Activist choice homophily and the crowdfunding of female founders. Administrative Science Quarterly, 62(2), 341-374.

Gu, B., Konana, P., Raghunathan, R., \& Chen, H. M. (2014). Research note-The allure of homophily in social media: Evidence from investor responses on virtual communities. Information Systems Research, 25(3), 604-617.

Hellmann, T., \& Thiele, V. (2015). Friends or foes? The interrelationship between angel and venture capital markets. Journal of Financial Economics, 115(3), 639-653.

Hernando, J. R. (2016). Crowdfunding: The collaborative economy for channeling institutional and household savings. Research in International Business and Finance, 38, 326-337.

Hornuf, L., \& Schwienbacher, A. (2016). 15 Crowdinvesting: angel investing for the masses?. Handbook of research on business angels, 381.

Hu, L. \& Gorbatai, A. D. (2015). What is the Crowd Worth? The Role of Social Influence in Crowdfunding.

Kang, Y. S., \& Herr, P. M. (2006). Beauty and the beholder: Toward an integrative model of communication source effects. Journal of Consumer Research, 33(1), 123-130.

Kelley, E. K. \& Tetlock, P. C. (2013). How wise are crowds? Insights from retail orders and stock returns. The Journal of Finance, 68, 1229-1265.

Kerr, W. R., Lerner, J., \& Schoar, A. (2011). The consequences of entrepreneurial finance: Evidence from angel financings. The Review of Financial Studies, 27(1), 20-55.

Kim, K., \& Viswanathan, S. (2018). The 'Experts' in the Crowd: The Role of Experienced Investors in a Crowdfunding Market.

Kuppuswamy, V., \& Bayus, B. L. (2017). Does my contribution to your crowdfunding project matter?. Journal of Business Venturing, 32(1), 72-89. 
Landström, H., \& Mason, C. (Eds.). (2016). Handbook of research on business angels. Edward Elgar Publishing.

Lee, J. G., \& Thorson, E. (2008). The impact of celebrity-product incongruence on the effectiveness of product endorsement. Journal of advertising research, 48(3), 433-449.

Lee, N., Sameen, H., \& Cowling, M. (2015). Access to finance for innovative SMEs since the financial crisis. Research Policy, 44(2), 370-380.

Mahmood, A., Luffarelli, J., \& Mukesh, M. (Forthcoming). What's in a logo? The impact of complex visual cues in equity crowdfunding. Journal of Business Venturing.

Mason, C., \& Botelho, T. (2014). The 2014 survey of business angel investing in the UK: A changing market place. Glasgow: Adam Smith Business School.

Mason, C., Botelho, T., \& Harrison, R. (2016). The transformation of the business angel market: empirical evidence and research implications. Venture Capital, 18(4), 321-344.

Maula, M., Autio, E., \& Arenius, P. (2005). What drives micro-angel investments?. Small Business Economics, 25(5), 459-475.

McKenny, A. F., Allison, T. H., Ketchen, D. J., Short, J. C., \& Ireland, R. D. (2017). How Should Crowdfunding Research Evolve? A Survey of the Entrepreneurship Theory and Practice Editorial Board. Entrepreneurship Theory and Practice, 41(2), 291-304.

Mollick, E. (2014). The dynamics of crowdfunding: An exploratory study. Journal of Business Venturing, 29, 1-16.

Mollick, E. \& Robb, A. (2016). Democratizing innovation and capital access. California Management Review, 58, 72-87.

Parhankangas, A., \& Renko, M. (2017). Linguistic style and crowdfunding success among social and commercial entrepreneurs. Journal of Business Venturing, 32(2), 215-236.

Plummer, L. A., Allison, T. H. \& Connelly, B. L. (2016). Better together? Signaling interactions in new venture pursuit of initial external capital. Academy of Management Journal, 59, $1585-1604$.

Rogers, E. M., \& Bhowmik, D. K. (1970). Homophily-heterophily: Relational concepts for communication research. Public opinion quarterly, 34(4), 523-538.

Shiller, R. J. (2015). Opinion: do crowdfunding rules ignore human nature? http://www.marketwatch.com/story/crowdfunding-or-crowdphishing-2015-11-18

Signori, A., \& Vismara, S. (2016). Returns on investments in equity crowdfunding.

Sørheim, R. \& Botelho, T. (2016). Categorisations of business angels: an overview. Handbook of Research on Business Angels, 76-91.

Sørheim, R., \& Landström, H. (2001). Informal investors-A categorization, with policy implications. Entrepreneurship \& Regional Development, 13(4), 351-370. 
Spence, A. (1973). Job Market Signaling. The Quarterly Journal of Economics, 87(3), 355-374.

Statista. (2018) Crowdinvesting (United Kingdom). Retrieved 22 June, 2018, Available at: https://www.statista.com/outlook/377/156/crowdinvesting/united-kingdom\#

TechCrunch. (2016). Crowdfunding is dead. https://techcrunch.com/2016/05/16/equitycrowdfunding-is-dead/

UKBAA. (2018). Be an angel | UK Business Angels Association (UKBAA). https://www.ukbaa.org.uk/services-for-investors/be-an-angel/ [last accessed 16/11/2018]

Vismara, S. (2016a). Equity retention and social network theory in equity crowdfunding. Small Business Economics, 46(4), 579-590.

Vismara, S. (2016b). Information Cascades Among Investors in Equity Crowdfunding. Entrepreneurship Theory and Practice. doi:10.1111/etap.12261

Vulkan, N., Åstebro, T. \& Sierra, M. F. (2016). Equity crowdfunding: A new phenomena. Journal of Business Venturing Insights, 5, 37-49.

Wallmeroth, J., Wirtz, P., \& Groh, A. P. (2018). Venture capital, angel financing, and crowdfunding of entrepreneurial ventures: A literature review. Foundations and Trends in Entrepreneurship, 14(1), 1-129.

Wright, M., Westhead, P., \& Sohl, J. (1998). Editors' introduction: Habitual entrepreneurs and angel investors. Entrepreneurship Theory and practice, 22(4), 5-22.

Wright, M., Hart, M., \& Fu, K. (2015). A nation of angels: Assessing the impact of angel investing across the UK. Enterprise Research Centre.

Zhang, B., Wardrop, R., Rau, R., \& Gray, M. (2015). Moving mainstream: the European alternative finance benchmarking report. University of Cambridge and EY. 